\title{
The BMJ statins papers misrepresent the facts
}

\author{
Peter Sever professor of clinical pharmacology \\ Imperial College London, London W2 1LA, UK
}

I fully support Rory Collins's request that The BMJ retracts Abramson and colleagues' and Malhotra's papers. ${ }^{1-3}$ The authors totally misrepresent Zhang and colleagues' claims that statins were causally related to side effects in $20 \%$ of statin users. ${ }^{4}$ The two papers also imply that these side effects were not reported in trials because trial sponsors could have influenced the results and downplayed the drugs' side effect profiles.

As co-chief investigator of ASCOT, ${ }^{5}$ an independently designed and led trial, in which the data were analysed and published independently of the funder, Pfizer, I strongly refute such implications. In ASCOT, we detected drug related side effects of the angiotensin converting enzyme inhibitor (cough) and the calcium channel blocker (ankle oedema). ${ }^{6}$ So if statins were causally related to myalgia or myopathy, why did we not detect this in a trial of 10000 people? ? $^{7}$ Adverse events and withdrawals from treatment were identical in those taking placebo or statin. Perhaps the answer is provided by a recent study, where rechallenge of patients previously withdrawn from statin because of myalgia, yielded the return of identical symptoms with both statin and placebo. ${ }^{8}$

The effect of these papers ${ }^{2}{ }^{3}$ is that, for the wrong reasons, patients whose future morbidity and mortality from cardiovascular disease would have benefited substantially from statin therapy, will be dissuaded from taking the drugs or will discontinue them if they are already receiving treatment.

The BMJ has taken a strong position on scientific integrity, and its condemnation of the Lancet's publication of the Wakefield measles, mumps, and rubella scandal was well received. The same principles should apply over the critical reviews of these two statin papers. The reporting of bad science is the prerogative of the lay press, not The BMJ.

Competing interests: I acknowledge receipt of grants to Imperial College London for the conduct of ASCOT and honorariums for lectures from Pfizer.

Full response at: www.bmj.com/content/348/bmj.g3306/rr/700606.

1 Godlee F. Adverse effects of statins. BMJ 2014;348:g3306. (15 May.)

2 Abramson JD, Rosenberg HG, Jewell N, Wright JM. Should people at low risk of cardiovascular disease take a statin? BMJ 2013;347:f6123.

3 Malhotra A. Saturated fat is not the major issue: let's bust the myth of its role in heart disease. BMJ 2013;347:f6340.

4 Zhang H, Plutzky J, Skentzos S, Morrison F, Mar P, Shubina M, et al. Discontinuation of statins in routine care settings. Ann Intern Med 2013;158:526-34.

5 Sever PS, Dahlöf B, Poulter NR, Wedel H, Beevers G, Caulfield M, et al. Rationale, design, methods and baseline demography of participants of the Anglo-Scandinavian Cardiac Outcomes Trial. ASCOT investigators. J Hypertens 2001;6:1139-47.

6 Sever PS, Dahlöf B, Poulter NR, Wedel H, Beevers G, Caulfield M, et al; ASCOT investigators. Prevention of coronary and stroke events with atorvastatin in hypertensive patients who have average or lower-than-average cholesterol concentrations, in the Anglo-Scandinavian Cardiac Outcomes Trial-Lipid Lowering Arm (ASCOT-LLA): a multicentre randomised controlled trial. Lancet 2003;361:1149-58.

7 Dahlöf B, Sever PS, Poulter NR, Wedel H, Beevers DG, Caulfield M, et al; for the ASCOT Investigators. Prevention of cardiovascular events with an antihypertensive regimen of amlodipine adding perindopril as required versus atenolol adding bendroflumethiazide as required, in the Anglo-Scandinavian Cardiac Outcomes Trial-Blood Pressure Lowering Arm (ASCOT-BPLA): a multicentre randomised controlled trial. Lancet 2005;366:895-906

8 Joy TR, Monjed A, Zou GY, Hegele RA, McDonald CG, Mahon JL. N-of-1 (single-patient) trials for statin-related myalgia. Ann Intern Med 2014;160:301-10. 